\title{
The Role of Religiosity as a Mediating Variable in the Relationship between Online Transactions and Customer Satisfaction and Loyalty in Islamic Banking
}

\author{
Suryari Purnama ${ }^{1}$, Andyani Sukmasari ${ }^{2}$, Rahul Bhandari ${ }^{3}$ \\ 1 Universitas Esa Unggul, Jl. Arjuna Utara No 9, Jakarta, Indonesia \\ ${ }^{2}$ STIE MNC, Jl. Arteri Kedoya, Jakarta, Indonesia \\ ${ }^{3}$ Jindal Global University, India \\ e-mail: suryaripurnama@esaunggul.ac.id ${ }^{1}$, andyanisukmasari@gmail.com² ${ }^{2}$, \\ rbhandari@jgu.edu.in
}

To cite this document :

Purnama, S., Sukmasari, A., \& Bhandari, R. (2021). The Role of Religiosity as a Mediating Variable in the Relationship between Online Transactions and Customer Satisfaction and Loyalty in Islamic Banking. Aptisi Transactions on Management (ATM), 5(2), 143-151.

DOI :

https://doi.org/10.33050/atm.v5i2.1532

Abstract
The purpose of this study to determine the role of religiosity as mediation in the relationship between online transactions and customer satisfaction and loyalty in Sharia banking in the Jakarta area. The population of this research is all sharia banking customers in Jakarta. The number of samples in this study was 175 Sharia banking customers in Jakarta by sampling purposive sampling method. The research method used Structural Equation Modelling Lisrel. The results showed: 1) there is no effect of failure on the experience of online transactions; 2) there is an effect of service recovery on the customer experience of online transactions; 3 ) there is an influence of customer experience on customer satisfaction in online transactions; 4) there is an effect of customer satisfaction on customer loyalty using online transactions; 5) customer religiosity moderates between customer experience to satisfaction using online transactions; 6 ) Customer religiosity moderates the satisfaction of customer loyalty using online transactions. As for the novelty of this study, religiosity affects customers in the relationship between customer experience and customer satisfaction and loyalty.

Keywords: Online Transaction Experience, Satisfaction, Loyalty, Religiosity

\section{Introduction}

Sharia banking in Indonesia has been operating since 1992, unfortunately sharia banks have not been able to reach the expected market share level. This is quite alarming, because Indonesia is one of the countries with a muslim population that has a percentage of more than $80 \%$. The phenomenon can actually occur due to several things. But most of it is caused by Sharia banking has not been able to reach the community completely. The size of the market share can certainly change according to changes in consumer tastes, or it can be said that consumers turn to competitors' products or services [1]. Good service to customers is very important to see the success of Sharia banking. It certainly needs support in terms of technology readiness such as e-banking facilities (mobile banking, internet banking and ATM) based on SST (Self Service Technology) [2].

There are several factors that say the lack of satisfaction and loyalty in Sharia banking [3]. As is the complaint of Sharia banking customers, there is a failure in the transaction process in sharia banks online, where the failure is caused by errors on the part of customers [4]. From the results of interviews conducted during the pretest, there were some problems in transacting online, such as customers mis-entering the amount of money, incorrectly entering the account number, the network / system was damaged so that the transaction was constrained, when the transaction was completed but did not issue receipts, and the withdrawal of the amount of money 
did not match the amount stated on the receipt and magnetiq chip was problematic so it could not make transactions [5] [6].

Therefore, the purpose of this research, focus on discussing the impact of SST failure, and recovery of SST on customer experience using online transaction services and its impact on customer satisfaction/ benefit and loyalty with moderation of customer religiosity [7][8][9]. Researchers want to see the extent to which customers will be satisfied and loyal to Sharia banking through online transactions after the failure and recovery of SST. That after SST failure will affect customer experience in online transactions SST failure recovery will impact on the online transaction experience [10]. Therefore, it is hoped that after experiencing failure in online transactions there will be a sense of satisfaction and customers will be loyal [11].

Seeing the rapid advancement of technology has changed most aspects of people's lives. As well as religiosity, it is important because it is able to influence individuals behaviorally as well as cognitively [12]. Religiosity is important to influence customer attitudes and preferences towards Islamic banking. religiosity is a very strong factor in influencing the satisfaction and loyalty of banking customers [13]. The application of religiosity, as a moderation variable opens new opportunities in research, so far research in Indonesia establishes religiosity in Sharia banking as a separate factor that is religiosity of customers, but supported by consumer behavior itself in dealing with Sharia banks [14].

\subsection{Literature Review}

\section{Self Service Technology}

Self service technologies that customers do without depending on employees with technology as intermediaries (web, internet banking, and ATM machines) [15]. The definition of SST is a self-service technology concept for customers, with the aspect of customers being able to control transactions performed as they wish, at the level where they want to interact, and how the end result of the transaction is done [10]. It can be said that increasing innovation based on information technology is important in the company's interaction with customers [16]. This is the key to long-term business success.

\section{Service Failure}

Service failure is defined as all service errors when a customer is involved with the service provider, so it can trigger negative emotions and the customer becomes dissatisfied [17]. Failure of service activities that occurred as a result of errors at the beginning of service received by customers, can be said not in accordance with customer expectations [18]. While service failure can be measured based that the failure of customer perception services based on the difference between customer predictions of SST performance in online transactions and the performance of products or services after using the product or service after the failure of the transaction [19].

\section{Service Recovery}

Service recovery as a plan, thought-out, and process to make up for the disappointment of what customers felt to be satisfied with the service provider after service recovery was performed due to failure. Seamless service restoration for customers voicing their dissatisfaction. The purpose of service recovery is to correct service failures that are indicated by customer complaints. The measurement of service recovery is seen from the customer perception of the recovery performance carried out by the independent service for service failures.

\section{Online Transaction Experience}

Customer experience is defined as subjective and internal responses when customers with the company engage in interactions, either directly or indirectly with the company. Customer experience will be enjoyable and satisfying when making purchase transactions online, of course it will affect the desire to find information and purchase intentions online in the future. Measurement of online transaction experience by looking at the thinking of customers' perceptions when shopping online based on their expectations for the services provided.

\section{Satisfaction}


Consumer satisfaction is a feeling that consumers feel both happy and disappointed, which arises after the consumer uses the results of the product or service. Consumer satisfaction is an evaluation of what consumers feel is based on their experiences after consuming certain services or products. So satisfaction is the level of assessment of a person related to services or product, related to the fulfillment of consumer needs. Measured customer satisfaction based on customer evaluation and impression on product and service performance [20].

\section{Loyalty}

Customer loyalty a situation where customers have a good attitude or perception of the brand, commit to the same brand and make continuous purchases in the future [21]. Companies that have loyal customers are certainly very meaningful because the cost of getting new customers is much higher when compared to retaining existing customers. Furthermore, the measurement of customer loyalty is to look at customer behavior regarding responses to products or services that have been consumed, thus causing customers to voluntarily volunteer to buy back and disseminate information about the product or service.

\section{Religiosity}

The definition of religiosity is an element that is imagined by the individual from the heart, the vibration of personal conscience and personal attitude [22]. To find out how far the religiosity of individuals, is based on beliefs, implementation, knowledge, and beliefs of Islam. Religiosity as a religion includes many things, not only doing worship activities, but other activities supported by supernatural powers. While a person's religiosity can be measured from the level of knowledge and understanding of a person based on the religion adopted.

\subsection{Hypothesis Development}

Effect After SST Failure on Customer Experience of Online Transactions in Sharia Banking With the presence of SST makes customers do not need to face-to-face, transactions will be easier and smoother with customers conducted online. Furthermore, it is expected that customers will gain good experience or not towards sharia banks. Affect and cognition as psychological variables, have consistently been identified as important components for customer experience and consumer behavior. Therefore, the quality of SST in sharia bank online software is very important to be improved because it has an impact on the poor assessment of the customer experience of transacting online. This is that there is an influence after the failure of SST on the experience of customers transacting online in Sharia banking. Based on the literature hypotheses that can be submitted:

$\mathrm{H} 1$ : There is an influence after the failure of SST on the experience of customers transacting online in Sharia banking

\section{The Effect of SST Failure Recovery on Customer Experience of Online Transactions in Sharia Banking}

Current SST users have improved and changed the way customers approach the company to interact in an effort to see the results of the self-service provided. However, service failures can occur, allowing the creation of unpleasant experiences when customers transact online. It was important for managers to understand the recovery of service failures because failure is one of the causes customers will turn to other service providers to make ends meet. If the recovery of Sharia bank services is not handled properly, then there will be a bad online transaction experience. This was supported that the recovery of SST failures has an influence on the customer experience of online transactions. Based on the literature hypotheses that can be submitted:

$\mathrm{H} 2$ : There is an effect of SST failure recovery on customer experience of online transactions in Sharia banking

The Effect of Customer Experience on Customer Satisfaction In Sharia Banking Online Transactions 
Customer satisfaction can be measured after experiencing a direct service experience. The quality of electronic services has an influence on customer satisfaction of Sharia Banks in Jordan. With self-service customers not only help themselves, but he also relies on SST services to make it easy for himself. In this case, the servicer makes it easy for customers to reward them for using SST, and they will continue to re-use it. Based on the literature hypotheses that can be submitted: H3: There is an influence of customer experience on customer satisfaction in online transactions in Sharia banking

\section{The Effect of Customer Satisfaction on Customer Loyalty Transacting Online In Sharia Banking}

The presence of ease of technology to transact online allows the occurrence of customer satisfaction, but the important thing is that the service of the products/services of the bank used has a role in determining customer satisfaction and dissatisfaction, where dissatisfaction can arise in the form of complaints about sharia bank services so that customers turn to other services. The attitude shown by customers can be said to be a form of disloyal attitude towards Sharia banks. Customer satisfaction has an influence on the loyalty of Sharia banking. Based on the literature hypotheses that can be submitted:

$\mathrm{H} 4$ : There is an influence of customer satisfaction on customer loyalty in online transactions in Sharia banking

\section{Effect of Customer Experience on Customer Satisfaction Online Transaction Moderated By Customer Religiosity}

Religiosity the main intermediary factor that encourages consumer behavior in Sharia banking services in Malaysia. Islamic values such as halal products, honesty, and humanity in religious activities give a positive perception of acceptance of services provided to Muslim consumers in Indonesia. Therefore, sharia banks as banks with Islamic principles certainly have services offered in accordance with established principles. Sharia principles certainly need to be used by Sharia banks in carrying out their operations, in order to obtain satisfaction. Therefore, if sharia banks do not run as the established principles, an unpleasant experience will be created. Based on the literature hypotheses that can be submitted:

H5: There is an effect of customer experience on customer satisfaction of online transactions moderated by customer religiosity.

\section{Effect of Customer Satisfaction on Customer Loyalty Online Transaction Moderated By Customer Religiosity}

As Muslims who have religiosity will certainly choose Sharia banks, as the main choice of banks to conduct financial transactions [23]. The value of an individual's religiosity will make the individual always try to adhere to the teachings of religion. Customers with high religiosity when obtaining the best quality of service in SST at sharia banks are expected to increase satisfaction [24]. Consumer satisfaction arises if what is expected is fulfilled so that it will have an impact on consumer loyalty [25]. Religiosity has an impact on customer satisfaction in the public sector in Pakistan [26]. Based on the literature hypotheses that can be submitted:

H6: There is an effect of customer satisfaction on customer loyalty in online transactions moderated by customer religiosity.

Based on the development of the hyphothesis, the research model is be described as follows:

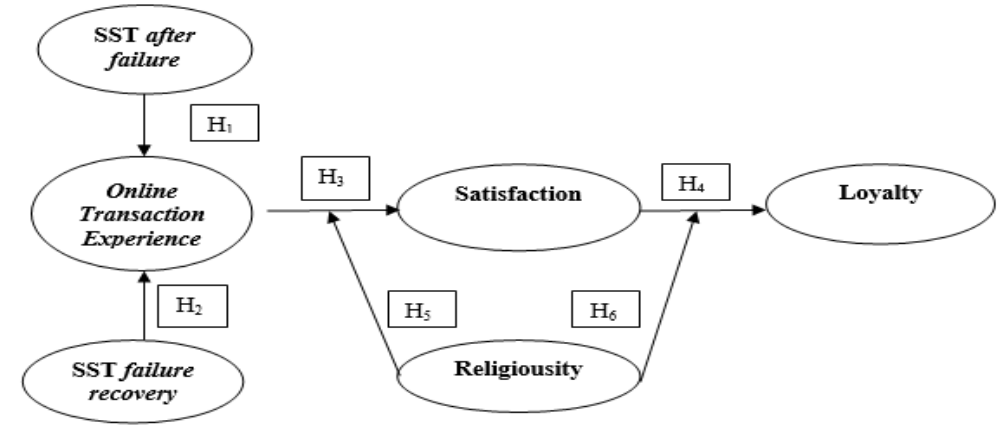

Figure 1. Research Model 


\section{Research Method}

In this research sharia banking customers in DKI Jakarta province, will become a research population. In accordance with the analysis tool that will be used, namely Structural Equation Model (SEM), the determination of the number of samples in sem provisions, at least 510 times the number of questionnaires [27]. The number of questionnaire statements in this study was 35 statements, so that the number of samples in this study $(35 \times 5) 175$ Sharia banking customers located in DKI Jakarta province, with the provision of having been a customer at least 3 years and customers aged at least 17 years. Furthermore, this research is quantitative research and there are exogenous variables (SST after failure and SST failure recovery), endogenous variables (online transaction experience, satisfaction, and loyalty), and moderation variables (religiosity). Furthermore, the SEM analysis method will be used to see the interrelationship between variables.

In this study, the data were obtained using questionnaires using likert scale method. Furthermore, validity test conducted on 30 respondents using confirmatory factor analysis results showed all kesioner statements on variableSST after failure, SST failure recovery, online transaction experience, satisfaction, loyalty and religiosity have been declared valid, with the provisions of KMO value and MSA anti image correlation $>0.500$ (Malhotra, 2014). Similarly, the reliability test of alpha cronbach value $>0.6$ showed good reliability and the result of all variables reliable with alpha cronbach $>0.6$.

\section{Results and Analysis}

\subsection{Analysis of Results with SEM}

This study focused on Sharia banking customers in Jakarta area with 145 samples as respondents. Furthermore, the results of analysis with SEM with Lisrel software showed, the first analysis of the measurement of construction validity test in this study results showed all variable indicators (SST after failure, SST failure recovery, online transaction experience, satisfaction, loyalty and religiosity) can be accepted with the provision of valid factor loading value $(>0.50)$, and $t$-value valid $(>1.96)$ at a level of significance of $5 \%$. Construction reliability reliabel test results are eligible when construct reliability values $(>0.60)$ and variance extracted $(>0.50)$ (Hair et al, 2014) and results showed all variables with CR value in SST after failure (0.82), SST failure recovery (0.84), online transaction experience (0.73), satisfaction (0.91), moderation of online transaction experience and religiosity (0.95), loyalty (0.90) and moderation of satisfaction and religiosity (0.81). While in VE value not all variables are reliabel in SST after failure (0.42), SST failure recovery $(0.52)$, online transaction experience $(0.63)$, satisfaction $(0.68)$, moderation of online transaction experience and religiosity $(0.88)$, loyalty $(0.64)$ and moderation of satisfaction and religiosity $(0.47)$.

Analysis of two structural tests by looking at the value of R2, serves to show how far independent variables are able to explain dependent variables: (1) together AF (SST after failure) and FR (SST failure recovery) affect OT (online transaction experience) with R2 value of 0.71 . This means that $71 \%$ of OT (online transaction experience) variants can be explained by AF (SST after failure) and FR (SST failure recovery) variables the remaining $29 \%$ are described other variables not contained in this study; (2) OT (online transaction experience) and moderation in OTR (online transaction experience religiosity) together affect satisfaction with a value of R2 of 0.74 . This means that $74 \%$ of the variants of satisfaction can be explained by ot variables (online transaction experience) and moderation in OTR (online transaction experience religiosity), the remaining $26 \%$ can be explained other variables that do not exist in this study; (3) K (satisfaction) and $K R$ (moderation on religiosity satisfaction) jointly affect loyalty with a value of $R 2$ of 0.27 . This means that $27 \%$ of loyalty variants are explained by variables K (satisfaction) and KR (moderation on religiosity satisfaction), the remaining $73 \%$ are described other variables that were not in the study.

Analysis of three, namely conformity test analysis of all models of group 1 to group 7 not all tests showed good fit: RMSEA and goodness of fit showed marginal fit results, Critical $\mathrm{N}$ showed poor fit, in Chi Square, ECVI, AIC and CAIC, Fit Index showed good fit. From the results of the analysis, it was concluded that the suitability of all models is still qualified because of the 7 groups, 4 groups are still good fit. Furthermore, the path diagram of the research results can be seen as follows: 


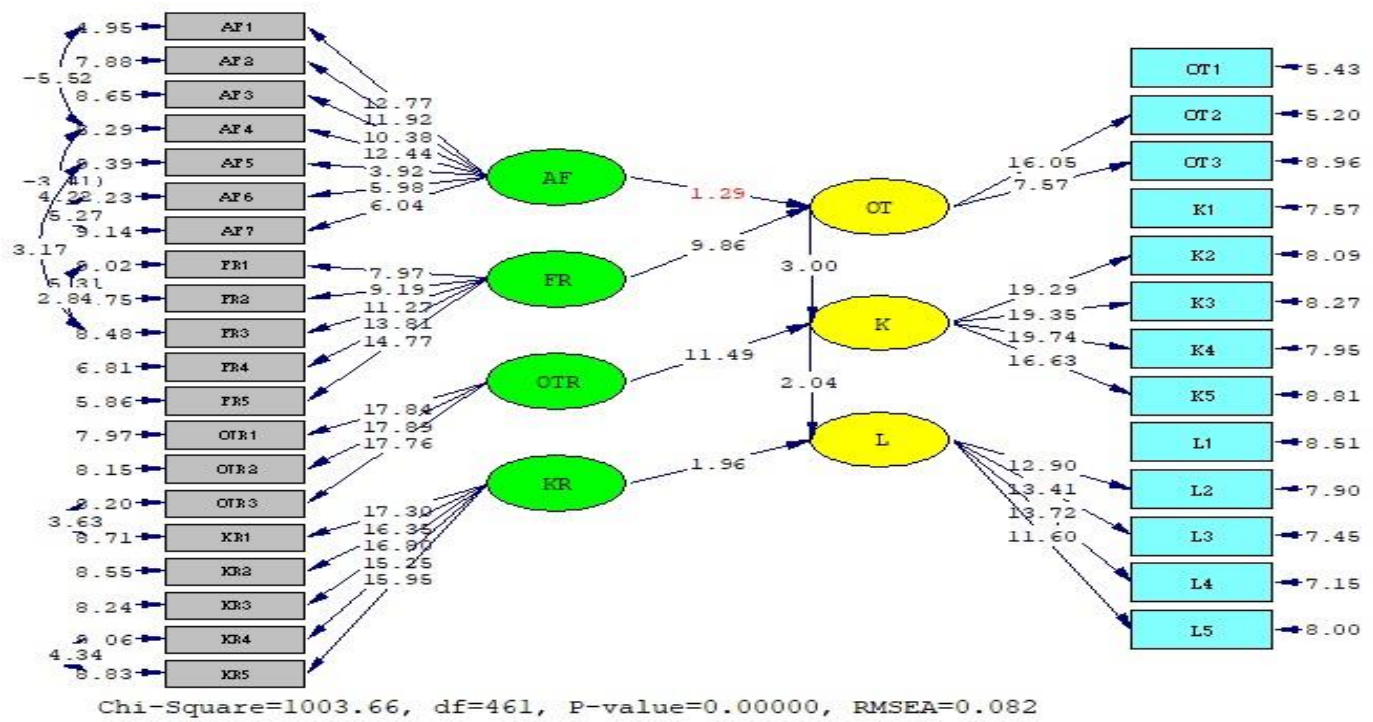

Figure 2. Path Diagram T. Value

Based on Figure 2 of the T-Value Path Diagram, the hypothetical results in this study can be seen in the following table:

Table 1. Hypothetical Test Results

\begin{tabular}{|c|l|c|c|}
\hline Hypothesis & \multicolumn{1}{|c|}{ Hypothetical statement } & $\begin{array}{c}\text { T-Value } \\
(\mathbf{1 , 9 6 )}\end{array}$ & Decision \\
\hline $\mathrm{H}_{1}$ & $\begin{array}{l}\text { There is an influence after the failure of } \\
\text { SST on the experience of online } \\
\text { transactions in Sharia banking. }\end{array}$ & 1,29 & Rejected \\
\hline $\mathrm{H}_{2}$ & $\begin{array}{l}\text { There is an effect of SST recovery on } \\
\text { customer experience using online } \\
\text { transactions in Sharia banking. }\end{array}$ & 9,86 & Accepted \\
\hline $\mathrm{H}_{3}$ & $\begin{array}{l}\text { There is an influence of customer } \\
\text { experience on customer satisfaction using } \\
\text { online transactions in Sharia banking. }\end{array}$ & 3,00 & Accepted \\
\hline $\mathrm{H}_{4}$ & $\begin{array}{l}\text { There is an effect of satisfaction on } \\
\text { customer loyalty using online transactions } \\
\text { in Sharia banking. }\end{array}$ & 2,04 & Accepted \\
\hline $\mathrm{H}_{5}$ & $\begin{array}{l}\text { Customer religiosity moderates the } \\
\text { customer's experience of satisfaction using } \\
\text { online transactions in Sharia banking. }\end{array}$ & 11,49 & Accepted \\
\hline $\mathrm{H}_{6}$ & $\begin{array}{l}\text { Customer religiosity moderates the } \\
\text { satisfaction of customer loyalty using } \\
\text { online transactions in Sharia banking. }\end{array}$ & 1,96 & Accepted \\
\hline
\end{tabular}




\subsection{Discussions}

The results of the first hypothesis test showed no influence after the failure of SST on the experience of customers transacting online in Sharia banking in Jakarta. This is not in line with previous studies. When there is a failure in the process of transacting online, most respondents realize that the failure occurred because of their own mistakes and also because the technology used is not the latest. Respondents can accept the failure as commonplace so that the failure event does not affect the experience of transacting.

The results of the second test showed that the recovery of SST failure had an effect on the customer experience of online transactions in the Jakarta area. This is supported, that SST has an influence on the customer experience of online transactions. When a company helps recover an SST failure, it creates a different experience to the experience at the time of failure. Failure recovery action is an effort that must be done by each company to gain the trust of its customers. Allah SWT created man with the best structure among other creatures of Allah SWT. For this reason, man is obliged to try and continue to pray to Him.

The results of the third test concluded that the customer experience has an influence on customer satisfaction in online transactions in the Jakarta area. The results of this study corroborate the findings of Al-Hawary and Al-Smeran (2017) that customer experience has an influence on customer satisfaction. Manufacturers should think about the many possibilities that will occur if the customer conducts self-service activities. Factors of accuracy, speed, and ease of service when conducting online transactions need to be considered, in order to avoid problems with customers. If customers feel that they always have problems doing online transactions in Sharia banks, then it can cause a negative impression on services in Sharia banks. Currently, online transactions are the main choice in bank services, customers do not need to set the time to make transactions face to face so that online transaction services become the vanguard, and this is in accordance with the expected maslahah.

The results of the four hypothesis test stated that customer satisfaction affects customer loyalty to online transactions at Sharia banks in the Jakarta area [28]. This is supported by the results of Leninkumar (2017); lqbal et al. (2017) that satisfaction has an influence on customer loyalty. Sharia banking has tried to provide the best quality of products and services to provide ease of customers in conducting online transactions. Ease of use of applications, interesting features, speed in conducting online transactions, and product performance can run as it functions, can provide customer satisfaction.

Furthermore, the five hypothesis testing showed religiosity moderating the customer's experience of online transaction satisfaction at sharia banks in the Jakarta area. This means that even if the customer has a poor experience but because there is an element of religiosity, the customer can still feel satisfaction, especially the recovery of failure is done precisely and quickly. Religiosity is an intermediary factor that encourages customer behavior towards Sharia banking services. Sharia banking as a bank with Islamic principles is able to attract customers with the religiosity of Islam owned. Hypothesis six test shows customer religiosity moderates between customer satisfaction to customer loyalty to online transactions at Sharia banks in the Jakarta area [29]. Customer satisfaction created by the influence of religiosity thus giving rise to the loyalty of Sharia banking customers [30]. Religiosity affects customer loyalty in Sharia banking in Bogor. Therefore, the bank must provide the best service when serving customers, both online and offline. With increasing customer satisfaction, customers will tend to be loyal to the company.

\section{Conclusion}

Based on this research, we can conclude three main things: (1) There is no effect of failure on the experience of online transactions in Sharia banking. Although failure reduces customer satisfaction, failure can also be seen as an opportunity to attract interest from customers by indemniing them for failures that occur; (2) There is an effect of SST recovery on customer experience using online transactions in Sharia banking, with SST restored it will increase customer satisfaction in online transactions; (3) There is an influence of customer experience on 
customer satisfaction using online transactions in Sharia banking, if the customer experience is positive it will increase customer satisfaction; (4) There is an effect of customer satisfaction on customer loyalty using sharia banking online transactions, meaning that high satisfaction will increase customer loyalty; (5) Customer religiosity moderates between customer experience to satisfaction using online transactions in Sharia banking, by including variable religiosity in the customer experience, the customer satisfaction increases in online transactions; (6) Customer religiosity moderates between satisfaction with customer loyalty using online transactions in Sharia banking, with religiosity in services in Sharia banking apparently increasing satisfaction that impacts loyal customers.

Conclusion two, if you look at the first conclusion, this can be the basic capital of Islamic banking in an effort to satisfy customers. If the customer is satisfied, there will be a sense of loyalty. It is hoped that with this loyalty, customers will promote indirectly to their families and their immediate environment regarding Islamic banking.

Conclusion three in order to develop research is suggested for future research to add other variables that can affect customer loyalty, for example, such as variables of consumer trust, service quality, and so on. Further research is also expected to be carried out on other research objects such as conventional banking, as well as other companies that use self service technology.

\section{Referensi}

[1] R. B. Porto, "Consumer-based brand equity of products and services: Assessing a measurement model with competing brands," Rev. Bras. Mark., vol. 17, no. 2, pp. 150165, 2018.

[2] A. M. Baabdullah, N. P. Rana, A. A. Alalwan, R. Islam, P. Patil, and Y. K. Dwivedi, "Consumer adoption of self-service technologies in the context of the Jordanian banking industry: Examining the moderating role of channel types," Inf. Syst. Manag., vol. 36, no. 4, pp. 286-305, 2019.

[3] M. Aisyah, "Islamic bank service quality and its impact on Indonesian customers' satisfaction and loyalty," Al-lqtishad J. Islam. Econ., vol. 10, no. 2, pp. 367-388, 2018.

[4] G. Shams, M. A. Rehman, S. Samad, and R. A. Rather, "The impact of the magnitude of service failure and complaint handling on satisfaction and brand credibility in the banking industry," J. Financ. Serv. Mark., vol. 25, pp. 25-34, 2020.

[5] N. Azizah, E. Suryana, and H. Haris, "Application of a Customer Based Data Monitoring Facility Online Accounting Software For Effectiveness Leadership at Higher Education," Aptisi Trans. Manag., vol. 1, no. 2, pp. 86-93, 2017.

[6] S. Syafryadin, "The Effect of Talking Chips Technique Toward the Improvement of Students' Speaking Achievement at one of the Senior High Schools in Bandung," Linguist. J. Linguist. Lang. Teach., vol. 6, no. 2, pp. 1-13, 2020.

[7] E. Depiana and H. Hartelina, "Marketing Service on Customer Satisfaction of Yamaha Motorcycles at PT Ramarayo Perdana Karawang," Aptisi Trans. Manag., vol. 5, no. 1, pp. 11-19, 2021.

[8] K. Mukerjee, "Impact of self-service technologies in retail banking on cross-buying and word-of-mouth," Int. J. Retail Distrib. Manag., 2020.

[9] H. Henderi, H. Zcull, and C. S. Putri, "Utilization of Testimonials Menu as Submission Media Information on Buyer Satisfaction on the Website E-Commerce Raharja Internet Café," Aptisi Trans. Technopreneursh., vol. 1, no. 1, pp. 101-108, 2019.

[10] J. E. Collier, M. Breazeale, and A. White, "Giving back the 'self' in self service: customer preferences in self-service failure recovery," J. Serv. Mark., 2017.

[11] T. Zhang, C. Lu, E. Torres, and P.-J. Chen, "Engaging customers in value co-creation or co-destruction online," J. Serv. Mark., 2018.

[12] A. Taves and E. Asprem, "Experience as event: event cognition and the study of (religious) experiences," Religion. Brain Behav., vol. 7, no. 1, pp. 43-62, 2017.

[13] D. Suhartanto, C. Gan, I. S. Sarah, and S. Setiawan, "Loyalty towards Islamic banking: service quality, emotional or religious driven?," J. Islam. Mark., 2019.

[14] D. Jamshidi and N. Hussin, "Forecasting patronage factors of Islamic credit card as a new e-commerce banking service," J. Islam. Mark., 2016.

[15] J. Gummerus, M. Lipkin, A. Dube, and K. Heinonen, "Technology in use-characterizing 
customer self-service devices (SSDS)," J. Serv. Mark., 2019.

[16] M. Lee et al., "How to respond to the fourth industrial revolution, or the second information technology revolution? Dynamic new combinations between technology, market, and society through open innovation," J. Open Innov. Technol. Mark. Complex., vol. 4, no. 3, p. 21, 2018.

[17] B. L. Cheng, C. C. Gan, B. C. Imrie, and S. Mansori, "Service recovery, customer satisfaction and customer loyalty: evidence from Malaysia's hotel industry," Int. J. Qual. Serv. Sci., 2019.

[18] R. Bagherzadeh, M. Rawal, S. Wei, and J. L. S. Torres, "The journey from customer participation in service failure to co-creation in service recovery," J. Retail. Consum. Serv., vol. 54, p. 102058, 2020.

[19] N. T. Le, S. Rao Hill, and I. Troshani, "Perceived control and perceived risk in self-service technology recovery," J. Comput. Inf. Syst., pp. 1-10, 2020.

[20] M. S. Dewi, R. A. N. Yuniati, and R. Akseptori, "Pengukuran Kinerja dengan Perspektif Keuangan dan Pelanggan (SK. Divisi HCM Grup Perusahaan Maritim Surabaya)," ADI Bisnis Digit. Interdisiplin J., vol. 1, no. 2, pp. 1-13, 2020.

[21] F. Hussein and H. Hartelina, "After Sales Service For Smartphone Iphone To Customer Loyalty," Aptisi Trans. Manag., vol. 5, no. 1, pp. 62-72, 2021.

[22] D. Espírito Santo, "Possession consciousness, religious individualism, and subjectivity in Brazilian Umbanda," Religion, vol. 47, no. 2, pp. 179-202, 2017.

[23] H. Usman, P. Tjiptoherijanto, T. E. Balqiah, and I. G. N. Agung, "The role of religious norms, trust, importance of attributes and information sources in the relationship between religiosity and selection of the Islamic bank," J. Islam. Mark., 2017.

[24] M. A. Janahi and M. M. S. Al Mubarak, "The impact of customer service quality on customer satisfaction in Islamic banking," J. Islam. Mark., 2017.

[25] D. C. Ahrholdt, S. P. Gudergan, and C. M. Ringle, "Enhancing loyalty: When improving consumer satisfaction and delight matters," J. Bus. Res., vol. 94, pp. 18-27, 2019.

[26] M. Kashif, A. Zarkada, and R. Thurasamy, "The moderating effect of religiosity on ethical behavioural intentions," Pers. Rev., 2017.

[27] D. Khajeheian, A. M. Colabi, N. B. Ahmad Kharman Shah, C. W. J. Bt Wan Mohamed Radzi, and H. S. Jenatabadi, "Effect of social media on child obesity: Application of structural equation modeling with the Taguchi method," Int. J. Environ. Res. Public Health, vol. 15, no. 7, p. 1343, 2018.

[28] T. Kartika, A. Firdaus, and M. Najib, "Contrasting the drivers of customer loyalty; financing and depositor customer, single and dual customer, in Indonesian Islamic bank," J. Islam. Mark., 2019.

[29] M. Tabrani, M. Amin, and A. Nizam, "Trust, commitment, customer intimacy and customer loyalty in Islamic banking relationships," Int. J. Bank Mark., 2018.

[30] W. Ramadayanti and K. Kosasih, "The Influence of Financial Performance on People's Business Credit in Banking Companies for the Period 2010-2019," Aptisi Trans. Manag., vol. 5, no. 1, pp. 73-78, 2021. 